\title{
Accuracy of Local Knowledge in Prediction of Seasonal Weather: Empirical Evidence from North Eastern Nigeria
}

\author{
Ahmed Abubakar Jajere ${ }^{1}$, Joshua, Jonah Kunda ${ }^{2}$, Umar Muhammed Bibi ${ }^{3}$ \& Yusuf Maina-Bukar ${ }^{4}$ \\ ${ }^{1}$ Department of Geography, Federal University Kashere, Gombe, Nigeria \\ ${ }^{2}$ School of Geography, University of Nottingham, Nottingham, UK \\ ${ }^{3}$ Department of Geography, Federal University Kashere, Gombe, Nigeria \\ ${ }^{4}$ Desert Research, Monitoring and Control Centre (DRMCC), Yobe State University, Damaturu, Nigeria \\ Correspondence: Joshua, Jonah Kunda, School of Geography, University of Nottingham, Nottingham NG7 2RD, \\ UK. E-mail: Jonah.joshua@nottingham.ac.uk
}

Received: March 27, 2021

Accepted: May 24, $2021 \quad$ Online Published: June 4, 2021

doi:10.5539/ep.v10n2p33

URL: https://doi.org/10.5539/ep.v10n2p33

\begin{abstract}
Over the years, West African Sahel's people developed some strategies for predicting the seasonal weather using meteorological indicators to plan for extreme weather events. This study used information on local indicators of seasonal weather prediction and mean monthly rainfall and temperature record (1981-2017) from Nguru weather station located at Latitude $14^{\circ} \mathrm{N}$ in achieving the aim of the study. Both qualitative and quantitate (descriptive and inferential) statistical tools were employed in analysing the collected data. The study found that the local population of the study area used meteorological indicators in predicting the seasonal weather. The results of the analysis revealed that the variability of the annual rainfall during the study period was large. An increasing trend of $3.1 \mathrm{~mm}$ annually was observed. While decreasing trend in the cold, dry and hot dry season temperature and an increasing trend in warm moist temperature by $0.025^{\circ} \mathrm{C}, 0.05^{\circ} \mathrm{C}$ and $0.0004^{\circ} \mathrm{C}$ respectively, was observed. Annual rainfall amount accounts for $31 \%$ and $2 \%$ variability in cold dry and warm moist season temperature, respectively. Cold, dry season and warm moist season temperature respond to any $1 \mathrm{~mm}$ increase in annual rainfall by decreasing by $0.012^{\circ} \mathrm{C}$ and $0.002^{\circ} \mathrm{C}$, respectively. The Hot, dry season temperature also accounts for $4 \%$ of the variability in annual rainfall. The model's result revealed anyone $1{ }^{\circ} \mathrm{C}$ increase in hot dry season temperature lowers the annual rainfall by $10 \mathrm{~mm}$. This study confirmed that the observed relationship between seasons weather conditions by local population exist. Therefore annual rainfall is the major determinant of cold dry seasonal temperature in the study area.
\end{abstract}

Keywords: climate variability, indigenous knowledge and seasonal weather prediction

\section{Introduction}

The people of West African Sahel, primarily farmers and Pastoralist, have been copping with large scale seasonal weather condition variability. According to Bibi et al (2014) the areas in the Northeast of Nigeria beyond the 120 latitudinal line is prone to drought and climate variability. The three distinct seasons (Hot dry, Cold Dry and wet) temporal variability are extreme. The climate-sensitive livelihoods in the fragile ecosystem respond significantly to any slide fluctuation in seasonal weather condition. Accurate information on what the seasonal weather will be like, remained the major constraint to local population climate variability copping strategies. Over the years, people developed some strategies for predicting the seasonal weather that enable them to plan for extreme weather events. The use of meteorological, astronomical and biological indicators by several African societies for centuries in predicting local weather and climate is reported in several studies (Chang, Yanda and Ngana, 2010; Makwara 2013; Okonya and Kroschel 2013). The local knowledge on weather/climate prediction techniques has attracted the attention of scientific research in several parts of African societies (Kijazi, Chang'a, Liwenga, Kanemba and Nindi 2013; Enock 2013; Chikaire, Ajaero, Ibe, Orusha and Onogu, 2018; Zuma-Netshiukhwi, Stigter and Walker, 2013 ). The studies broadly identified the predicting variables, and little attention is given to validating the effectiveness and accuracy level of local predictions techniques. Thus, a need to evaluate the accuracy and validity of weather prediction using local knowledge, especially in the West African Sahel ecological belt. The focus of satellitederived weather forecast information is mainly on rainfall. The established relationship between West African 
Sahel rainfalls with Sea Surface temperature enables a more accurate rainfall forecast using satellite data. Little attention is given to seasonal temperature. At the same time, Harmattan season weather is vital to the economy and livelihood in general of the people of Sahel. According to the local knowledge of the people of Sahel, the intensity of Harmattan season temperature is the function of the annual rainfall pattern. Therefore it is against this backdrop that this study validated the meteorological indicators of local Knowledge weather predictions using historical climate data from the weather station in a part of the West African Sahel.

\section{Literature/Theoretical Underpinning}

Local knowledge is a total sum of experience people accumulated over time through interaction with the environment or society (Makwara, 2013). Some of the knowledge is passed from generation to generation and developed over time. Local knowledge is the human capital of societies. It is the principal asset they invest in the struggle to survive, which encompasses skills and insight people apply to maintain and improve their livelihoods (Makwara, 2013 citing Williams and Muchena 1991). Today much local Knowledge system are at risk of becoming extinct (Radeny, Desalegn, Mubiru, Kyazze, Mahoo, Recha, Kimeli and Solomon, 2019). Local population livelihoods are climate-sensitive. Thus climatic variability poses a threat to fragile livelihoods that depends on mother earth. The Local population predict seasonal climate to plan for the extreme event. The local population used local environmental and astronomical indicators in predicting seasonal weather (Radeny, et-al 2019). The Local Knowledge of weather predictions has attracted the attention of scientific studies in recent years. The studies primarily focused on identifying the indicators for documentation and integration in seasonal weather prediction techniques.

Chang'a, Liwenga Kanemba and Nindi (2013) reported that local communities of Mahenge and Ismani wards, Tanzania, used Plant phenology particularly that of mango trees, in predicting the rainfall pattern. An assessment of the forecasted and observed 2011/2012 seasonal rainfall indicates comparable results. Chang'a, Yanda and Ngana (2010), in their study on Indigenous knowledge in seasonal rainfall prediction in the South-western Highland of Tanzania, found that the local communities widely used plant phenology in seasonal rainfall forecasting. Early and significant flowering of Mihemi (Erythrina abyssinica) and Mike (Brachystegia speciformis) trees from July to November has been identified to be one of the signals of the excellent rainfall season. The behaviour of the Dudumizi bird has been singled out as one of the best indicators for rainfall. Local farmers of South Eastern Nigeria predict the dry season and harmattan using fruits drying/falling off from trees, increasing termites, shedding of the tree, and appearance of rainbows, among others. Okonya and Kroschel (2013) reported that Uganda's local communities used meteorological indicators such as wind direction and cloud colour in predicting rainfall. Improve accuracy and reliability of seasonal weather forecast need to be enhanced in the present increasing climatic variability over most of the world posed global climate change. Therefore "Systematic documentation and subsequently integration of Indigenous Knowledge (IK) in seasonal rainfall forecasting is one of the promising initiatives that need to be explored" (Chang'a, Yanda and Ngana 2010).

\section{Methodology}

Three decades' monthly rainfall and temperature records from Nguru (Latitude $14^{\circ}$ ) were sourced from Northeast Arid Zone Development Programme (NEAZDP) meteorological Stations. The data contained monthly rainfall records used to calculate the mean annual rainfall, monthly max, min, and seasonal temperature. The local knowledge indicators used in seasonal weather prediction was sourced through Participatory Rural Appraisal (PRA) methods namely key informant interviews and Focus Group Discussions (FGDs) were used in Identification of the traditional indicators used for seasonal rainfall forecast in Sahel Savannah of North eastern Nigeria. A total of four villages two each from Agro-pastoralist and agrarian communities (Dagona, Dachia, Maimalari and Garin lamido) were sampled as shown in figure 1. 


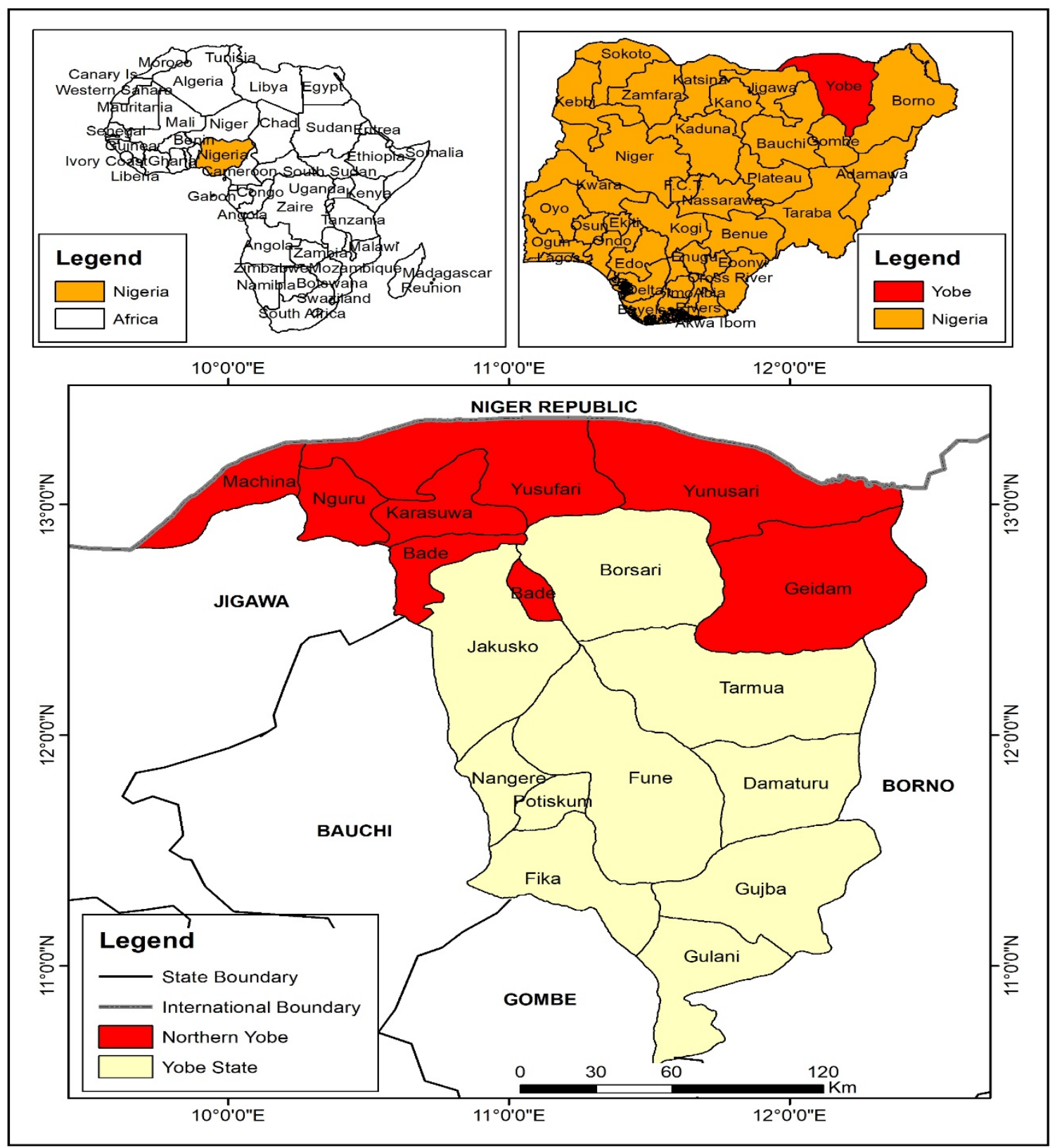

Figure 1. Agro-pastoralist and agrarian communities of North eastern Nigeria

The selection of the villages was not systematic; it was mainly based on the accessibility to the respective villages and history. The interview and discussion questions explored perceptions on climate variability and various techniques used within the community in seasonal weather forecasting. Content analysis technique was used in analysing information collected from key informants interviews and FGDs.

The annual temperature of the station was divided in to three temperature seasons: hot/dry, warm/moist and cold/dry.

\section{Hot/dry season = March, April, May and June mean temperature}

Warm $/$ moist $=$ July, August, September and October mean temperature

Cold/dry $($ Harmattan $)=$ November, December, January and February mean temperature

Annual Rainfall $=$ total rainfall that falls in the year

Linear regression statistical tool was used in determining annual rainfall and Seasonal temperature variability trend 
during the study period

$$
Y t=f(T)
$$

Where $Y t=$ annual rainfall and temperature

T = time

Explicit for

$Y_{t}=\lambda_{o}+\lambda_{I} T$

Where $\lambda_{o}=$ constant

$\lambda_{1}=$ coefficient of time

$$
C D S T=f(\text { Annual Rainfall) }
$$

$$
\begin{aligned}
& C D S T_{t}=\alpha_{0}+\alpha_{1} A R F_{t}+e_{t} . \\
& \text { WMST }_{t}=\alpha_{0}+\alpha_{1} A R F_{t}+e_{t} . \\
& A R F_{t}=\alpha_{0}+\alpha_{1} \operatorname{HDST}_{t}+e_{t}
\end{aligned}
$$

\section{Results and Discussion}

Local indicators used for seasonal weather prediction

Table 1. People perception on reliability of local indicators for weather prediction

\begin{tabular}{ll}
\hline Indicators & Reliability \\
\hline Astronomical & Fair \\
Meteorological & Excellent \\
Plants phenology & Good \\
Animals behavior & Good \\
\hline
\end{tabular}

The discussant generally agreed that the use of meteorological indicators in seasonal weather prediction is the most reliable. The use of astronomical indicators lack expertise as very few people have the knowledge now. This is because of the religious believe that is discouraging the use of astronomical knowledge in prediction.

Table 2. Knowledge on local indicators based on seasonal weather

\begin{tabular}{ll}
\hline Signs & Descriptions in relation to seasonal weather \\
\hline Annual rainfall amount & $\begin{array}{l}\text { The higher the total annual rainfall the lower the cold dry and warm moist seasonal } \\
\text { (hamattan) and temperature }\end{array}$ \\
$\begin{array}{l}\text { Hot dry season } \\
\text { temperature }\end{array}$ & The higher the hot dry season temperature the higher the annual rainfall amount \\
Wind speed & The higher the hot dry seasonal wind speed the higher the annual rainfall \\
\hline
\end{tabular}

Rainfall variability pattern of Nguru (1981-2017)

The descriptive statistics of Nguru station monthly rainfall (1981-2017) are presented in table 3 and figure 2. The decadal standardised precipitation index and annual rainfall variability trend are presented in table 4 and figure 2 . 
Table 3. Nguru monthly rainfall descriptive statistics (1981-2017)

\begin{tabular}{lllllllll}
\hline & MEAN & MAX & MIN & STDV & Skewness & Kurtosis & $\begin{array}{l}\text { Coefficient } \\
\text { of Variance }\end{array}$ & $\begin{array}{l}\text { Count of rain }>51 \mathbf{m m} \\
\text { (\%) }\end{array}$ \\
\hline JAN & 0 & 0 & 0 & 0 & - & - & 0 & 0 \\
FEB & 0 & 0 & 0 & 0 & - & - & 0 & 0 \\
MCH & 0.4 & 14 & 0 & 2.4 & - & 34 & 536 & 0 \\
APR & 3 & 38 & 0 & 8.4 & 2.9 & 8.8 & 248 & 0 \\
MAY & 8.8 & 49 & 0 & 12 & 1.9 & 3.9 & 131 & 0 \\
JUN & 33 & 110 & 4 & 24 & 1.2 & 1.3 & 73 & 30 \\
JUL & 135 & 314 & 29 & 62 & 0.5 & 0.3 & 42 & 92 \\
AUG & 161 & 281 & 74 & 49 & 0.6 & 0.7 & 29 & 100 \\
SEP & 62 & 186 & 5 & 35 & 1.1 & 3.1 & 57 & 0 \\
OCT & 5 & 39 & 0 & 8 & 2.7 & 8.1 & 186 & 0 \\
NOV & 0 & 0 & 0 & 0 & - & - & - & 0 \\
DEC & 0 & 0 & 0 & 0 & - & - & - & 0 \\
RDY & 31 & 53 & 17 & 8 & 0.5 & 0.7 & 25 & - \\
ARF & 408 & 616 & 237 & 85 & -0.5 & -0.3 & 19 & - \\
DRT & 63 & 95 & 35 & 15 & - & - & 24 & - \\
\hline
\end{tabular}

Source: Author Analysis (2018)

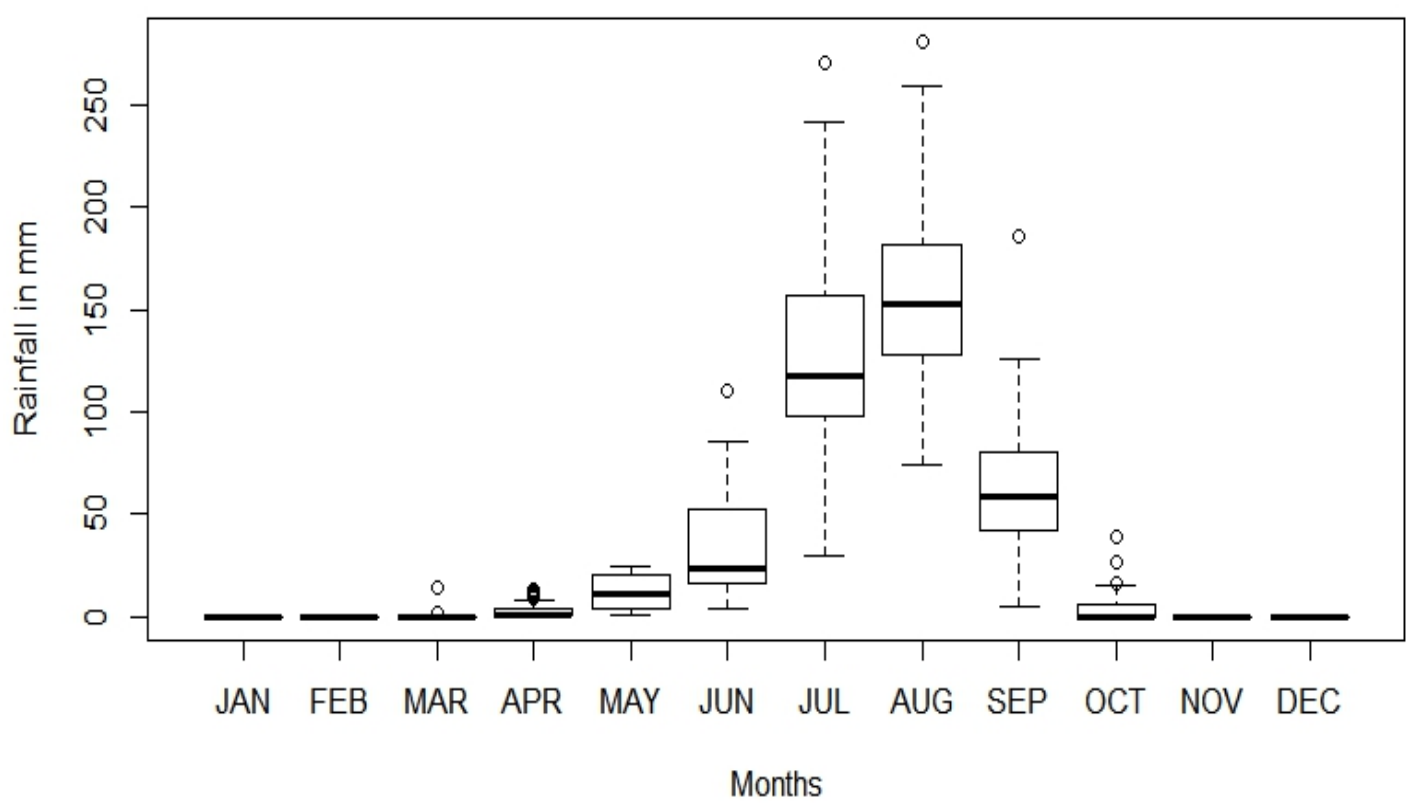

Figure 2. Nguru monthly rainfall distribution rainfall (1981-2017)

Source: Author Analysis (2018) 


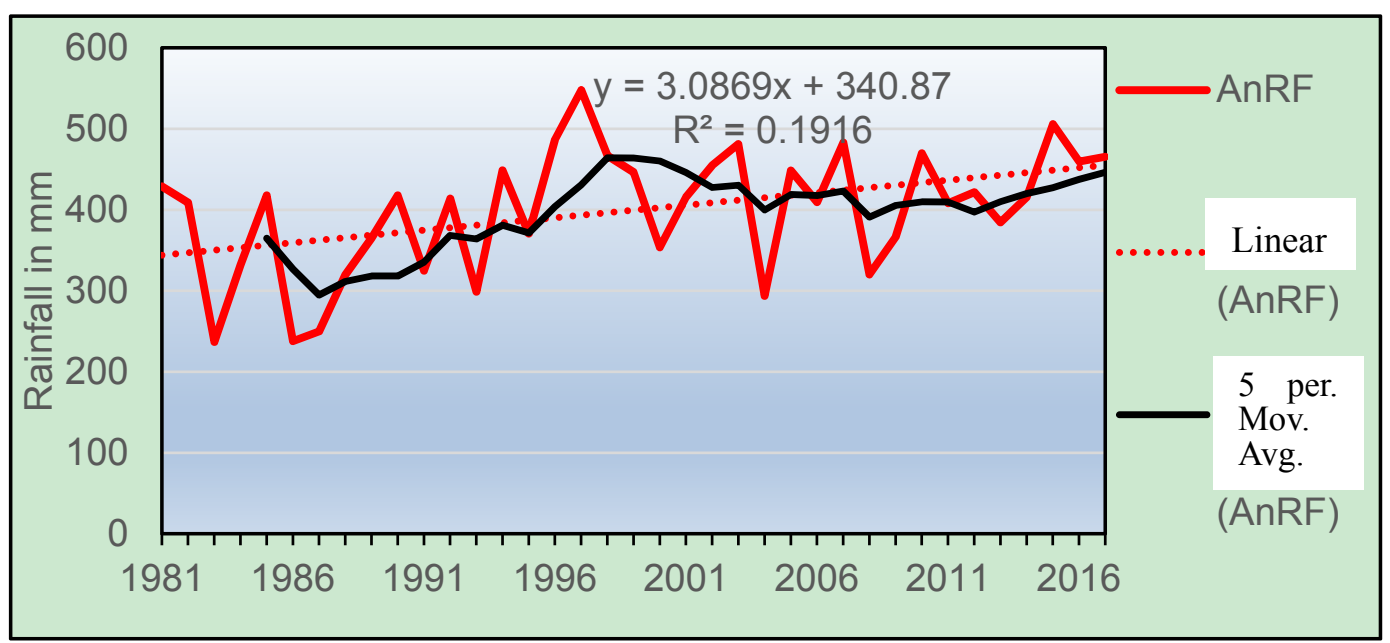

Figure 3. Nguru annual rainfall variability trend (1981-2017)

Source: Author Analysis (2018)

The analysis results revealed significant year-to-year variability in rainfall characteristics around these 37 years (1981-2017) averages, much more than Potiskum station (Jajere 2020). The variability in rainfall attributes of the station was significant in the 1980s up till 1990s and lower between 2000 to 2018, as in fig.3 while, Jury and Isabella, 2002; Anyamba and Tucker, 2005 report decreasing trend in the amounts of rainfall with increasing variability in the West African Sudano-Sahelian region, in the last 50years (1963-2013). Annual rainfall and rainy days fluctuate between the Maximum of $616 \mathrm{~mm}$ to a minimum of $237 \mathrm{~mm}$ and a Maximum of 53days to a minimum of 17 days, respectively. Large scale variability in annual rainfall and rainy days was observed with a standard deviation of $85 \mathrm{~mm}$ from the average of $408 \mathrm{~mm}$ and 8days from the average 31days, respectively. Monthly, the onset and cession months of July and September shows large variability with a standard deviation of $62 \mathrm{~mm}$ from the average of $135 \mathrm{~mm}$ and $35 \mathrm{~mm}$ from the average of $62 \mathrm{~mm}$, respectively. The annual rainfall variability trend result shows an increasing annual trend of $3.1 \mathrm{~mm}$. Thus, the variability is statistically insignificant at a $0.2 \mathrm{R} 2$ value.

Every month, the station records precipitation from March to October. Thus, the threshold of $51 \mathrm{~mm}$ was recorded from July to September within the study period. Except for August, the Minimum rainfall below $51 \mathrm{~mm}$ was recorded in all of the month within the period. The Month of August, which records the peak of the season, shows a dramatic variability trend with a Maximum of $161 \mathrm{~mm}$ and a minimum of $74 \mathrm{~mm}$, which is slightly above $51 \mathrm{~mm}$ thresh hold. As shown in figure 6, the station records eight rainy months with only three months with a rainfall threshold of $51 \mathrm{~mm}$. 


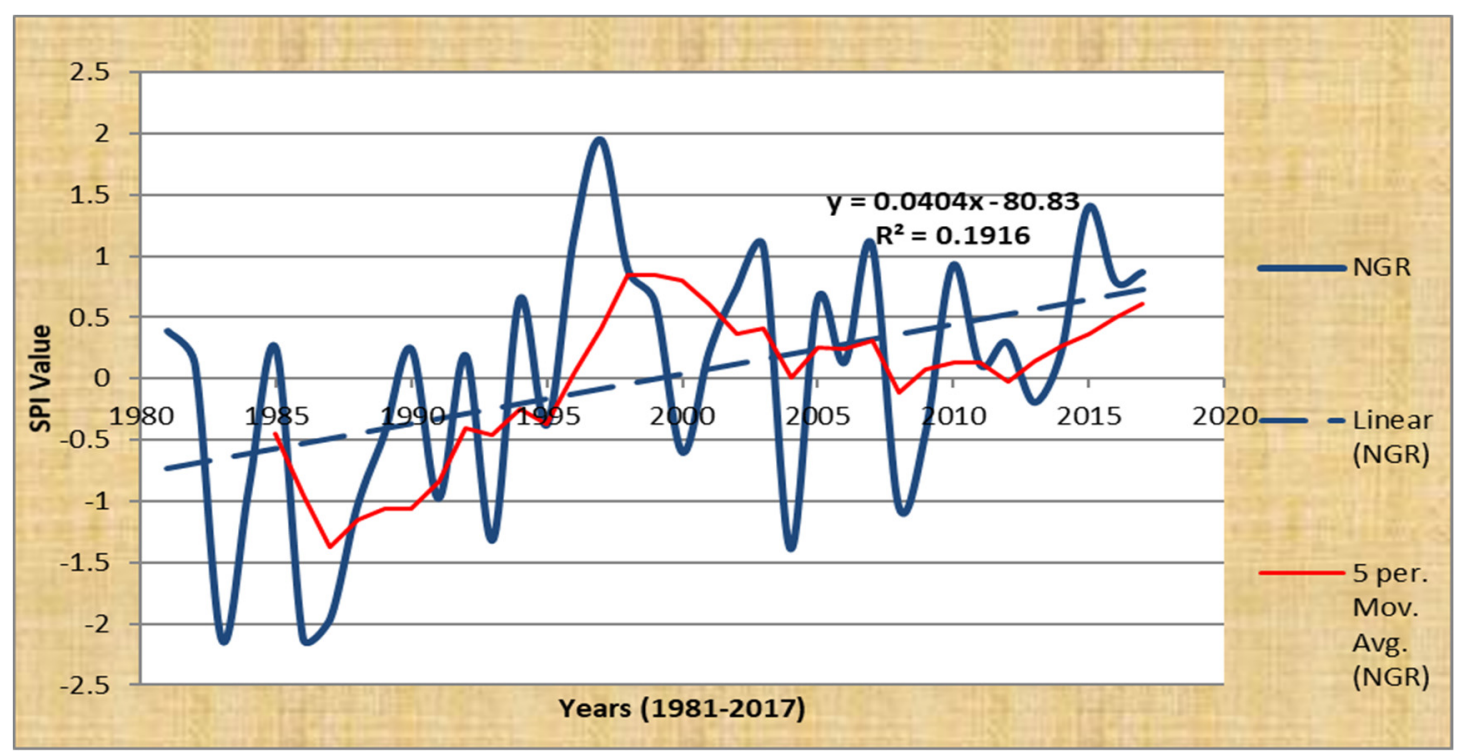

Figure 4. Nguru station SPI variability trend (1981-2017)

Source: Author Analysis (2018)

Table 4. Descriptive summary of Nguru station SPI (1981-2017)

\begin{tabular}{llcc}
\hline $\begin{array}{l}\text { Drought Intensity } \\
\text { Categories }\end{array}$ & SPI Values & Number of Years & Percentage \\
\hline Extremely wet & $>2$ & 0 & 0 \\
Very wet & 1.5 to 1.99 & 1 & 3 \\
Moderately wet & 1 to 1.50 & 4 & 11 \\
Near normal & -0.99 to 0.99 & 25 & 68 \\
Moderately drought & -1 to -1.49 & 4 & 11 \\
Severally drought & -1.5 to -1.99 & 1 & 3 \\
Extremely drought & $-2<$ & 2 & 5 \\
\hline
\end{tabular}

Source: Author Analysis (2018) 


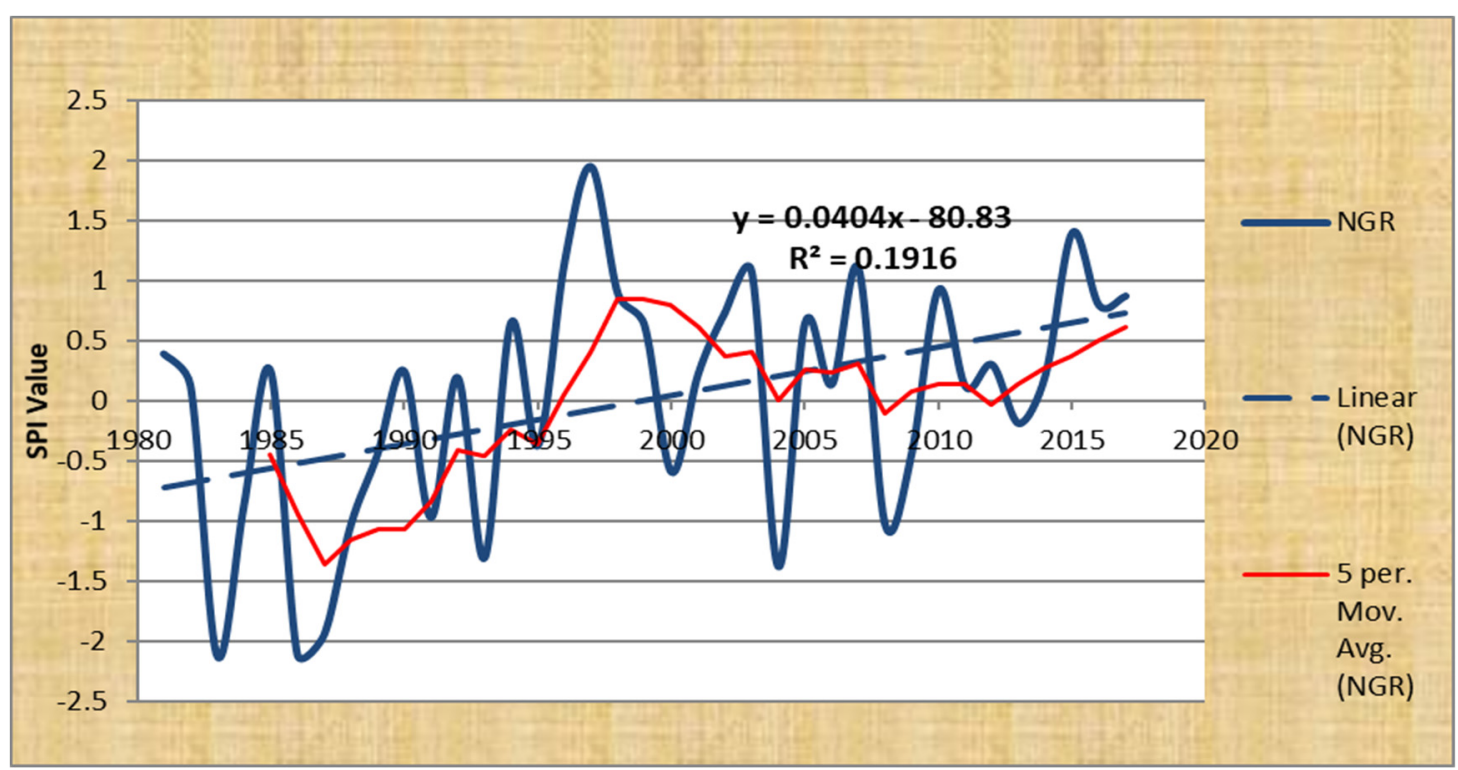

Figure 5. SPI trend and moving averages in Nguru (1981-2017)

Source: Author Analysis (2018)

Within the study period, the rainfall pattern at Nguru records 25 years of near-normal wetness. The station recorded 7years of dryness; extreme drought in 1983 and 1986, severe drought in 1986, moderate drought in 1988, 1993, 2004 and 2008. Five (5) years of wetness were also recorded, with a very wet season in 1997 and moderate wetness in 1996, 2003, 2007 and 2015. This study's findings confirm Usman, Abdulhamid, and Sawa (2015) that reports shift toward wetter condition. A similar study by Stephen and Tobi (2014) in their study of 90years of rainfall distribution across all climatic zones of Nigeria report common change points and transitions from dry to wet (upward shift) in all climatic zones.

Table 5. Decadal rainfall seasonality indices in KYRB Downstream (1981-2017)

\begin{tabular}{lcl}
\hline Period & Seasonality Index & \multicolumn{1}{c}{ Remark } \\
\hline $\mathbf{1 9 8 1 - 1 9 9 0}$ & 1.3 & Most rain in three months or less \\
$\mathbf{1 9 9 1 - 2 0 0 0}$ & 1.2 & Most rain in three months or less \\
$\mathbf{2 0 0 1 - 2 0 1 0}$ & 1.2 & Most rain in three months or less \\
$\mathbf{2 0 1 1 - 2 0 1 7}$ & 1.4 & Most rain in three months or less \\
\hline
\end{tabular}

Source: Author Analysis (2018)

The seasonality index analysis from 1981 to 2017 revealed that seasonal rainfall spread is primarily concentrated within 3months. Thus, the higher values observed in the 1980s and 2011-2017 reveal that the rainfall spread during the periods occurs in less than 3 months. 


\subsection{Nguru Station Temperature Pattern during the Study Period}

Table 6. Descriptive summary of seasonal temperature of Nguru (1981-2017)

\begin{tabular}{lllllllllllll}
\hline & \multicolumn{3}{c}{ Mean temp } & \multicolumn{4}{c}{ Max temp } & \multicolumn{4}{c}{ Min temp } & \multicolumn{3}{c}{ Diurnal temp } \\
\cline { 2 - 13 } & CDS & HDS & MWS & CDS & HDS & MWS & CDS & HDS & MWS & CDS & HDS & MWS \\
\hline Mean & 23.8 & 30.6 & 28.0 & 29.9 & 37.1 & 33.5 & 17.7 & 24.2 & 22.5 & 12.2 & 13.0 & 11.0 \\
Max & 25.6 & 32.3 & 29.4 & 33.0 & 39.2 & 35.7 & 20.7 & 26.3 & 25.7 & 17.7 & 16.8 & 14.1 \\
Min & 20.6 & 28.5 & 26.1 & 25.0 & 34.6 & 31.15 & 14.1 & 21.7 & 20.5 & 8.1 & 9.9 & 6.3 \\
Stdv & 1.4 & 0.9 & 0.9 & 2.24 & 1.12 & 1.23 & 1.3 & 1.2 & 1.24 & 2.3 & 1.3 & 1.7 \\
Skwe & -0.9 & -0.8 & -0.2 & -0.8 & -0.3 & -0.02 & -0.5 & -0.1 & 0.9 & 0.18 & -0.1 & -0.5 \\
Kurt & -0.1 & 0.11 & -0.8 & -0.1 & -0.4 & -0.8 & 1.1 & -0.4 & 0.7 & -0.6 & 1.4 & 0.41 \\
CV & 2.05 & 0.9 & 0.8 & 5.0 & 1.3 & 1.5 & 1.7 & 1.3 & 1.5 & 5.19 & 1.8 & 2.97 \\
\hline
\end{tabular}

Note; CDS, Cold dry season; HDS, Hot dry season; MWS, Moist warm season

Source: Author's Analysis (2018)

\subsection{Nguru Station Cold Dry Season Temperature Pattern during the Study Period}

The cold, dry season at Nguru Station falls between months November to February, with January being the coldest month. The Maximum cold, dry season temperature of Nguru fluctuates between the Maximum of $33^{\circ} \mathrm{C}$ to Minimum of $25^{\circ} \mathrm{C}$ with a standard deviation of $2.2^{\circ} \mathrm{C}$ from the average of $30^{\circ} \mathrm{C}$. At the same time, the minimum temperature of the season fluctuates between the Maximum of $20.7^{\circ} \mathrm{C}$ to Minimum of $14.1^{\circ} \mathrm{C}$ with a standard deviation of $1.3^{\circ} \mathrm{C}$ from the average of $17.7^{\circ} \mathrm{C}$. The cold, dry season begins in mid of November and ends in the mid of March. The result of monthly temperature descriptive statistics revealed that March is colder than November Within the season. The maximum temperature falls below $30^{\circ} \mathrm{C}$ between December and February, while the minimum temperature falls below $17^{\circ} \mathrm{C}$. The variability in the cold, dry season temperature revealed large scale variability of $30 \%$, with an annual decreasing trend of $0.1^{\circ} \mathrm{C}$ during the study period.

\subsection{Nguru Station Hot Dry Season Temperature Pattern during the Study Period}

The hot, dry season at Nguru Station falls between months April to July, with May been the hottest month. The Maximum hot, dry season temperature of Nguru fluctuates between the Maximum of $39.15^{\circ} \mathrm{C}$ to Minimum of $34.6^{\circ} \mathrm{C}$ with a standard deviation of $1.1^{\circ} \mathrm{C}$ from the average of $37.1^{\circ} \mathrm{C}$. In contrast, the minimum temperature of the season fluctuates between the Maximum of $25.6^{\circ} \mathrm{C}$ to Minimum of $20.6^{\circ} \mathrm{C}$ with a standard deviation of $1.4^{\circ} \mathrm{C}$ from the average of $23.8^{\circ} \mathrm{C}$. The maximum temperature of the season rises above $40^{\circ} \mathrm{C}$ between April and July, while the minimum temperature falls below $30^{\circ} \mathrm{C}$. The variability in hot, dry season temperature revealed small scale variability of $10 \%$, with an annual decreasing trend of $0.05^{\circ} \mathrm{C}$ during the study period.

\subsection{Nguru Station Warm Moist Season Temperature Pattern during the Study Period}

The Maximum moist warm-season temperature of Nguru fluctuates between the Maximum of $35.7^{\circ} \mathrm{C}$ to Minimum of $31.2^{\circ} \mathrm{C}$ with a standard deviation of $1.2^{\circ} \mathrm{C}$ from the average of $33.5^{\circ} \mathrm{C}$. In comparison, the minimum temperature of the season fluctuates between the Maximum of $25.7^{\circ} \mathrm{C}$ to Minimum of $20.5^{\circ} \mathrm{C}$ with a standard deviation of $1.2^{\circ} \mathrm{C}$ from the average of $22.5^{\circ} \mathrm{C}$. The maximum temperature of the season falls below $38.5^{\circ} \mathrm{C}$ between August and October, while the minimum temperature falls below $29^{\circ} \mathrm{C}$. The variability in warm moist season temperature revealed variability of only $0.5 \%$, with an increasing annual trend of $0.005^{\circ} \mathrm{C}$ during the study period. 


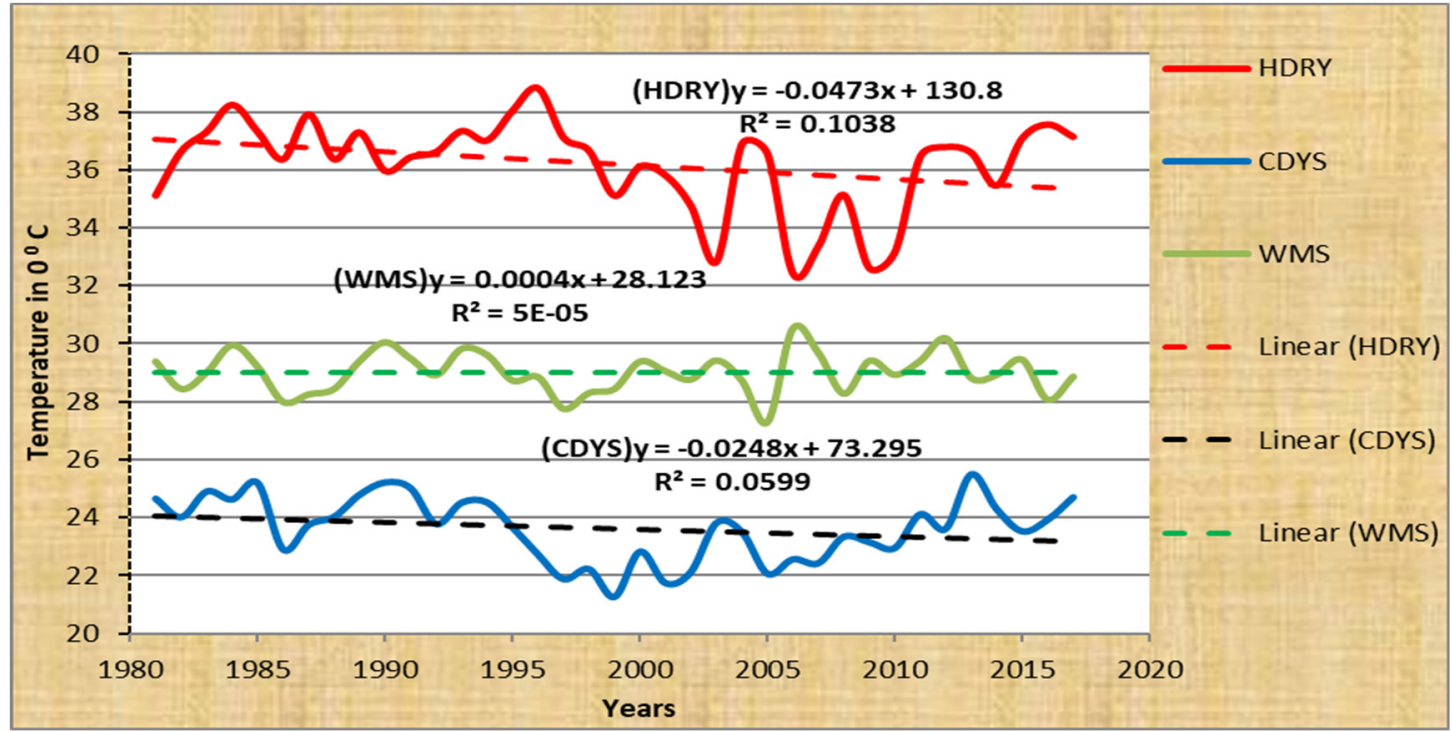

Figure 6. Nguru Seasonal Temperature Variability Trend

Source: Author Analysis (2018)

\subsection{Relationship between Annual Rainfall and Seasonal Temperature}

Theoretically, rainfall amount influence temperature at both local and regional scale. The local knowledge of people in the Sahel on seasonal rainfall and temperature prediction shows that there is a relationship between rainfall and cold, dry season temperature and hot, dry season temperature and seasonal rainfall pattern.

Table 7. Annual rainfall and seasonal temperature of Nguru

\begin{tabular}{lllll}
\hline & CDS & HDS & WMS & Ann RF \\
\hline CDS & 1 & -0.222 & 0.085 & $-0.424^{* *}$ \\
HDS & 0.222 & 1 & $-0.36^{*}$ & -0.282 \\
WMS & 0.085 & $-0.36^{*}$ & 1 & 0.091 \\
Ann RF & $-0.424^{* *}$ & -0.282 & 0.091 & 1 \\
** Significant at $99 \%$ & $*$ Significant at $95 \%$ & & \\
$(\mathrm{CDS}=$ Cold dry season & HDS= Hot dry season & WMS = Warm moist season, Ann RF = Annual rainfall)
\end{tabular}

The result of the correlation coefficient in table 5 revealed a statistically significant negative relation between annual rainfall and cold, dry season temperature at a $99 \%$ level of significance. The impact of annual rainfall on cold, dry season temperature was estimated using linear regression. The result of the regression coefficient is presented in table 5 .

Table 8. Impact of annual rainfall on cold dry season temperature

\begin{tabular}{|c|c|c|c|c|c|c|}
\hline \multicolumn{7}{|c|}{ Coefficients } \\
\hline \multirow{2}{*}{\multicolumn{2}{|c|}{ Model }} & \multicolumn{2}{|c|}{ Unstandardized Coefficients } & \multirow{2}{*}{$\begin{array}{c}\text { Standardized Coefficients } \\
\text { Beta }\end{array}$} & \multirow[t]{2}{*}{$\mathbf{T}$} & \multirow[t]{2}{*}{ Sig. } \\
\hline & & B & Std. Error & & & \\
\hline \multirow[t]{2}{*}{1} & (Constant) & 34.753 & 1.213 & & 28.655 & .000 \\
\hline & ARF & -.012 & .003 & -.555 & -3.946 & .000 \\
\hline
\end{tabular}

a. Dependent Variable: CDST

Source: Author Analysis (2018) 
The local knowledge on climate variability prediction enables them to understand the relationship between annual rainfall and seasonal temperature. They assume that annual rainfall determines the Cold, dry season temperature, i.e. the higher the annual rainfall, the lower the cold, dry season temperature. This study used a linear regression equation model to validate their assumption. Based on the estimated model, the annual rainfall has a statistically significant negative impact on cold, dry season temperature. This implies that an increase in annual rainfall decreases the cold, dry season temperature; the annual rainfall pattern accounts for $31 \%$ variability in cold, dry season temperature. According to the model results, any $1 \mathrm{~mm}$ increases in annual rainfall decrease the cold, dry season temperature by $0.02^{\circ} \mathrm{C}$.

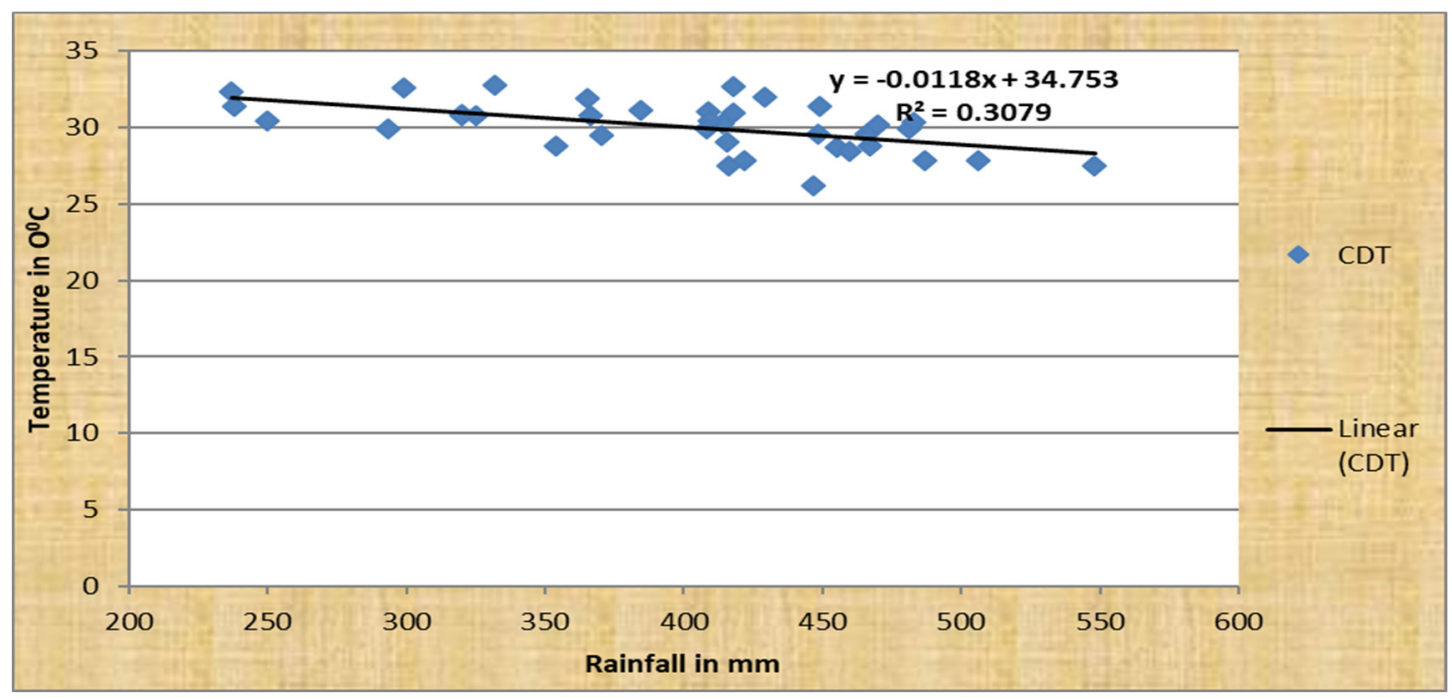

Figure 7. Relationship between rainfall and cold dry season temperature

Source: Author Analysis (2018)

Table 9. Regression coefficient of the impact hot dry season temperature on rainfall

\begin{tabular}{|c|c|c|c|c|c|c|}
\hline \multirow{2}{*}{\multicolumn{2}{|c|}{ Model }} & \multicolumn{2}{|c|}{$\begin{array}{c}\text { Unstandardized } \\
\text { Coefficients } \\
\end{array}$} & \multirow{2}{*}{$\begin{array}{c}\text { Standardized } \\
\text { Coefficients }\end{array}$} & \multirow[t]{2}{*}{$\mathbf{t}$} & \multirow[t]{2}{*}{ Sig. } \\
\hline & & B & Std. Error & & & \\
\hline \multirow[t]{2}{*}{1} & (Constant) & 765.316 & 287.363 & & 2.663 & .012 \\
\hline & HDRY & -10.109 & 7.934 & -.211 & -1.274 & .211 \\
\hline
\end{tabular}

Source: Author Analysis (2018)

According to their perception, the perceptions of the local population on rainfall variability prediction are that annual rainfall is a function of Hot dry season temperature, i.e. Hot dry season temperature is the major driver of annual rainfall variability according to their perception, the higher the hot, dry season temperature the lower the annual rainfall. The hot, dry season temperature has a statistically insignificant negative impact on annual rainfall based on the estimated model. This implies that an increase in hot, dry season temperature decrease the annual rainfall amount. According to the model results, any $1 \%$ increases in temperature during the hot, dry season decreases annual rainfall by $10 \mathrm{~mm}$. 


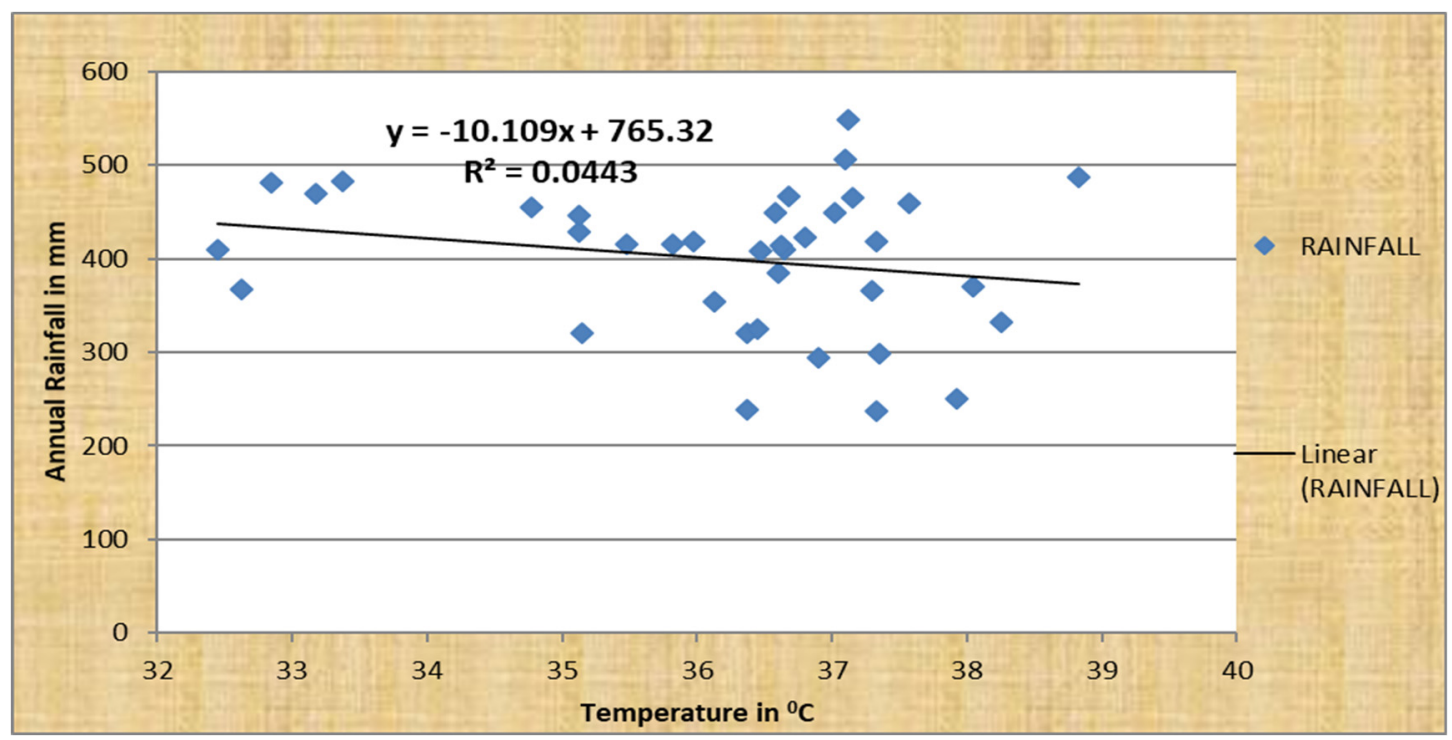

Figure 8. Relationship between rainfall and hot dry season temperature

Source: Author Analysis (2018)

Table 10. Regression coefficient of the impact hot dry season temperature on rainfall

\begin{tabular}{llrrrrrr}
\hline Model & \multicolumn{2}{c}{$\begin{array}{c}\text { Unstandardized } \\
\text { Coefficients }\end{array}$} & \multicolumn{2}{c}{$\begin{array}{c}\text { Standardized } \\
\text { Coefficients }\end{array}$} & t & Sig. \\
\cline { 3 - 5 } & & \multicolumn{1}{c}{ B } & Std. Error & Beta & & \\
\hline 1 & (Constant) & 35.272 & 1.053 & & 33.483 & .000 \\
& Ann RF & -.005 & 0.003 & -.282 & -1.738 & .091 \\
\hline
\end{tabular}

a Dependent Variable: MWST

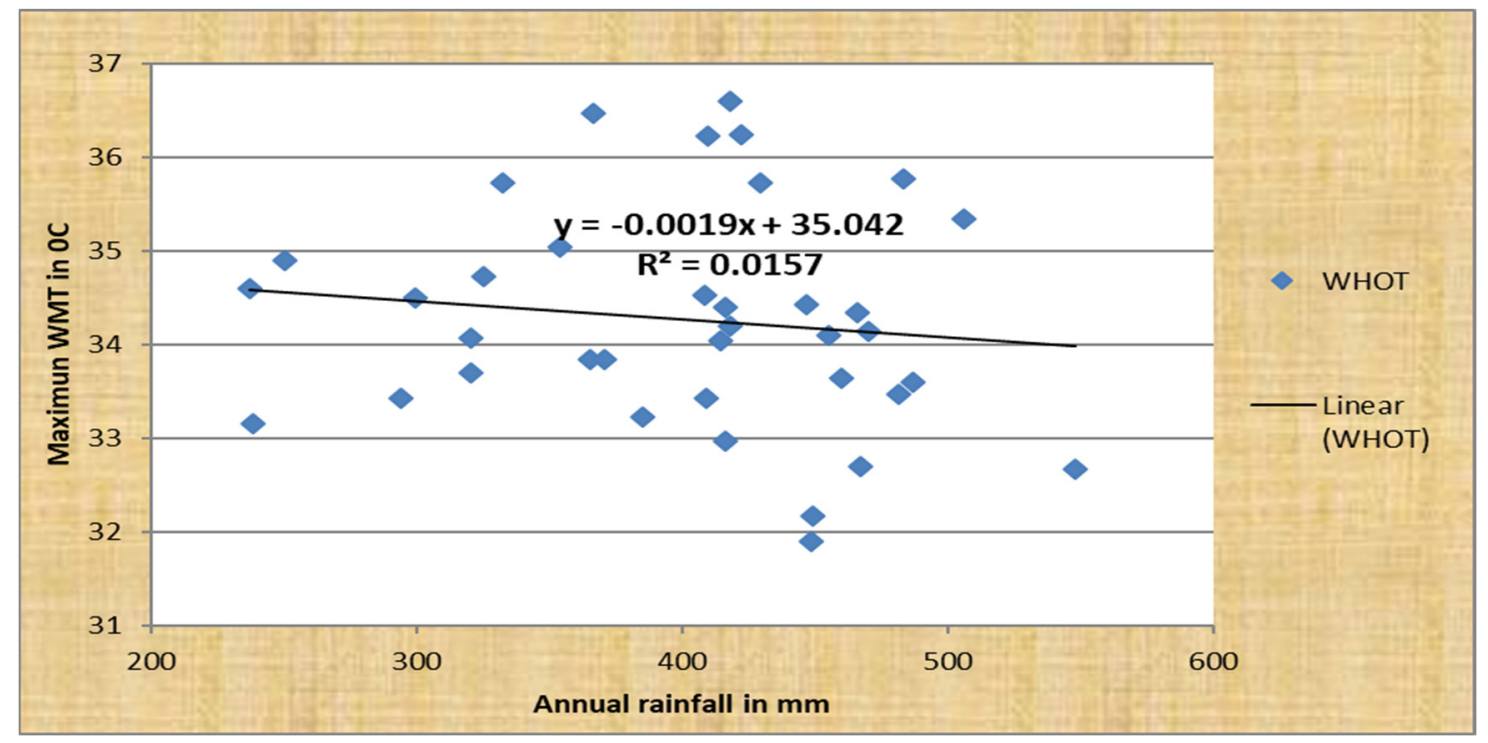

Figure 9. Relationship between rainfall and warm moist season temperature

Source: Author Analysis (2018) 
The linear regression analysis presented in fig.9 revealed that rainfall has a negative relationship with Warm moist season temperature (i.e. the higher the annual rainfall, the lower the warm moist season temperature). The result shows that the impact of annual rainfall on warm moist season temperature is not significant as it accounts for only $2 \%$ of the variability in warm moist season temperature. Any $1 \mathrm{~mm}$ increase in annual rainfall lower the warm moist season temperature by $0.002^{\circ} \mathrm{C}$

\section{Discussion}

The findings of this study are confirmed by the study of Tinyiko and John (2016). The study found a positive correlation between rainfall and temperature on the monthly time scale and a negative correlation between the variables on an annual time scale. Generally, the temperatures trend line within the study period shows a decreasing trend, as against the ICPC reports of an increase in average global temperature. The study of Aiyelokun Oluwatobi and Odekoya Oluwakemi (2016) on atmospheric temperature variability in Ijebu-Ode, Southwest Nigeria, with the use of parametric (Least Square Regression) and non-parametric (Mann Kendall) test. Reported a general increase in air temperature since 1983. Also, Dammo et al. (2015) reported a significant increase (positive trend) in temperature in North-Eastern Nigeria during 1981-2010. The temperature decreasing trend in the study area may not be unconnected with the rising rainfall of the Sahel. Several empirical studies reported a negative relationship between rainfall and temperature (Peter, 2012; Kevin and Denis, 2005; Rong-Gang and Mark, 2012). Available empirical studies on local knowledge on climate prediction in African largely focused on identifications and documentation of the indicators. (Ladislaus, Pius and James 2010; Kijazi et-al .2013; Chikaire J. U. et-al. 2018; Maren Radeny et-al. 2019) confirmed that rural farmer of different part of Africa used Astronomical, meteorological and biological indicators in weather forecasting. Although the accuracy level of local knowledge was not been adequately investigated. According to Maren Radeny et-al. (2019) coordinated research and systematic documentation of IK for weather forecasting, including accuracy and reliability of IK are steal largely lacking.

\subsection{The Implication to Research and Practice}

Rainfall and temperature are major climatic elements that determined the general ecosystem function and services. The type of crop to be produce and output is primarily a function of seasonal rainfall and temperature. Rainfall can be supplemented through irrigation, but temperature modification for crop production is impossible or costeffective. The Hamadan season temperature of Sahel fall low 30C, which can support the production of some temperature crops like Irish Potatoes. The result of this study will be used in regional agricultural planning and other developmental planning.

\section{Conclusion}

The rainfall variability result revealed significant year-to-year variability in rainfall characteristics around these 37years (1981-2017) averages. Every month, a threshold of 51mm was recorded from May to October. Within the study period, a $100 \%$ monthly threshold $(51 \mathrm{~mm})$ count was recorded only in August. The annual rainfall variability coefficient of 21 was recorded. Between 1981 to 2017, drought index results revealed that 5, 25 and 7 seasons of wetness, near normal and dryness was observed, respectively. Generally, the variability in rainfall attributes was significant in the 1980s up till the 1990s and lower between 2000 and 2017. The monthly temperature variability within the study period was large. Thus August and September show lower fluctuation when compared with other months. The mean annual temperature variability is much lower than the monthly and seasonal mean. Hot, dry season and cold, dry season temperature show more considerable variability than a warm moist season. The fluctuation of temperature attribute during the study period was significant in the 1980s to mid-1990s than what is observed in 2000 to 2017. Generally, the temperatures trend line within the study period shows a decreasing trend. The hot, dry season and cold, dry season temperature show a decreasing trend of $-0.05^{\circ} \mathrm{C}$ and $-0.025^{\circ} \mathrm{C}$ at a statistically significant R-value of 0.32 and 0.24 . In contrast, warm moist season temperature shows a statistically insignificant increasing trend of $0.0004^{\circ} \mathrm{C}$. Annual rainfall amount accounts for $31 \%$ and $2 \%$ variability in cold dry and warm moist season temperature, respectively. Cold, dry season and warm moist season temperature respond to any $1 \mathrm{~mm}$ increase in annual rainfall by decreasing by $0.012^{\circ} \mathrm{C}$ and $0.002^{\circ} \mathrm{C}$, respectively.

\section{References}

Aiyelokun, O., \& Odekoya, O. (2016). Analysis of Trend and Variability of Atmospheric Temperature in IjebuOde, Southwest Nigeria. International Research Journal of Agricultural Science and Soil Science, 6(2), 2531.

Anyamba and Tuckers. (2005). Analysis of Sahelian vegetation dynamics using NOAA-AVHRR NDVI data from 1981-2003. Journal of Arid Environments, 63, 596-614. https://doi.org/10.1016/j.jaridenv.2005.03.007 
Chang'a, L. B., Pius, Z. Y., \& James, N. (2010). Indigenous knowledge in seasonal rainfall prediction inTanzania: A case of the South-western Highland of Tanzania. Journal of Geography and Regional Planning, 3(4), 6672. Retrieved from http://www.academicjournals.org/JGRP

Chikaire, J. U., Ajaero, J. O., Ibe, M. N., Orusha, J. O., \& Onogu, B. (2018). Relevance of Indigenous Knowledge in Weather and Climate Forecast for Planning Farm Activities by Farmers in Imo State, Nigeria. Agri Res \& Tech: Open Access J, 19(1). https://doi.org/10.19080/ARTOAJ.2018.19.556082

Dammo, M. N., Ibn Abubakar, B. S. U., \& Sangodoyin, A. Y. (2016). Trend and Change Analysis of Monthly and Seasonal Temperature Series Over North-Eastern Nigeria. Journal of Geography, Environment and Earth Science International, 3(2), 1-8. https://doi.org/10.9734/JGEESI/2015/18512

Jajere, A. A. (2020). Wetlands Response to Climate Variability: Emperical Evendence from Kumadugu-Yobe River Basin. An Unpublished P.h. D thesis Submitted to Department Geography and Environmental Management. Ahmadu Bello University Zaria. Nigeria.

Jury, M. R., \& Isabelli, G. (2002). Decadal climate variability in the Eastern Caribbean. Journal of Geophysical Research: Atmospheres (1984-2012), 116(D21). https://doi.org/10.1029/2010JD015107

Kijazi, A. L., Chang'a, L. B., Liwenga, E. T., Kanemba, A., \& Nindi, S. J. (2013). The use of indigenous knowledge in weather and climate prediction in Mahenge and Ismani wards, Tanzania. Journal of Geography and Regional Planning, 6(7), 274-280. https://doi.org/10.5897/JGRP2013.0386

Ladislaus, B., Chang'a, Pius, Z. Y., \& James, N. (2010). Indigenous knowledge in seasonal rainfall prediction in Tanzania: A case of the South-western Highland of Tanzania. Journal of Geography and Regional Planning, 3(4), 66-72.

Makwara Enock, C. (2013). Indigenous Knowledge Systems and Modern Weather Forecasting: Exploring the Linkages. Journal of Geography and Regional Planning, 6(7), 274-280.

Maren, R., Ayal, D., Drake, M., Florence, K., Henry, M., John, R., Philip, K., \& Dawit, S. (2019). Indigenous knowledge for seasonal weather and climate forecasting across East Africa. Climatic Change, 156, 509-526. https://doi.org/10.1007/s10584-019-02476-9

Okonya, J. S., \& Jürgen, K. (2013). Indigenous knowledge of seasonal weather forecasting: A case study in six regions of Uganda. Agricultural Sciences, 4(12), 641-648. https://dx.doi.org/10.4236/as.2013.412086

Peter, E. A. (2012). An Assesment of Rainfall and Temperature Variations in Selected Stations in parts of Northern Nigeria. Ph.D Thesis A Thesis in the Department of Geography and Planning, University of Jos.

Radeny, M., Ayal, D., Drake, M., Florence, K., Henry, M., John, R., Philip, K., \& Dawit, S. (2019). Indigenous knowledge for seasonal weather and climate forecasting across East Africa. https://doi.org/10.1007/s10584019-02476-9

Rong-Gang, C., \& Mark, B. (2012). The Interdependence Between Rainfall and Temperature: Copula Analysis. The Scientific World journal. https:/doi.org/10.1100/2012//405675

Stephen, B. O., \& Tobi, E. M. (2014). Rainfall distribution and change detection across climatic zones in Nigeria. Weather and Climate Extremes, 5-6, 1-6. https://doi.org/10.1016/j.wace.2014.10.002

Usman, S. U., Abdulhamid, A. I., \& Sawa, B. A.(2015). An Assesement of Spatio-Temporal Variability of Drought in The Semi-arid Zone of Nigeria Using Standardized Precipitation Index. Zaria Geographer, 22(1), 98-108.

Zuma-Netshiukhwi, G., Kees, S., \& Sue, W. (2013). Use of Traditional Weather/Climate Knowledge by Farmers in the South-Western Free State of South Africa: Agrometeorological Learning by Scientists Atmosphere. https://doi.org/10.3390/atmos4040383

\section{Copyrights}

Copyright for this article is retained by the author(s), with first publication rights granted to the journal.

This is an open-access article distributed under the terms and conditions of the Creative Commons Attribution license (http://creativecommons.org/licenses/by/4.0/). 